\title{
PENGEMBANGAN MEDIA POP UP BOOK UNTUK PEMBELAJARAN MEMBACA PUISI KELAS I SD
}

\author{
Lutfiana Baroditus Sobakhah ${ }^{1)}$ \\ Pendidikan Guru Sekolah Dasar, Universitas muhammadiyah Gresik \\ lutfiana.sobakhah78@gmail.com \\ Afakhrul Masub Bachtiar ${ }^{2)}$ \\ Pendidikan Guru Sekolah Dasar, Universitas muhammadiyah Gresik \\ afakh1985@gmail.com
}

\begin{abstract}
Abstrak
Pengembangan Media Pop Up Book Untuk Pembelajaran Membaca Puisi pada Peserta Didik Kelas I SDN Prambangan. Penelitian ini bertujuan untuk mengembangkan media Pop Up Book untuk pembelajaran membaca puisi pada peserta didik kelas I SDN Prambangan. Jenis penelitian ini adalah penelitian pengembangan dengan menggunakan model pengembangan instruksional menurut Sadiman, dkk. (1996). Penelitian ini terdiri dari tujuh tahapan yang meliputi (1) identifikasi kebutuhan, (2) perumusan tujuan, (3) perumusan butir materi, (4) perumusan alat pengukur keberhasilan, (5) penulisan naskah media, (6) tes/uji coba, (7) revisi. Penelitian ini dilaksanakan di SDN Prambangan Jl. Mayjend Sungkono No.1 Prambangan, Kecamatan Kebomas, Kabupaten Gresik, Jawa Timur. Subjek dalam penelitian ini adalah peserta didik kelas I SDN Prambangan dengan jumlah peserta didik 11 siswa. Teknik pengumpulan data dalam penelitian ini adalah wawancara, validasi, dan tes dengan menggunakan instrumen penelitian berupa lembar wawancara, lembar validasi ahli, dan lembar tes. Teknik analisis data yang digunakan yaitu kualititatif. Hasil penelitian ini menunjukkan bahwa media Pop Up Book yang dikembangkan peneliti dalam segi komponen penyajian media berkategori "Sangat Baik" dengan hasil validasi mencapai 94,5\%, sedangkan dari segi kompetensi berkategori "Baik" dengan hasil validasi mencapai 86,7\%. Tingkat keberhasilan pengembangan media Pop Up Book menunjukkan hasil yang baik melalui uji coba dengan tes unjuk kerja secara terbatas yang mencapai 93,3\% dan berkategori "Sangat Baik" serta uji coba dengan tes unjuk kerja secara luas yang mencapai 86,0\% dan berkategori "Baik", sehingga rata-rata ketercapaian keberhasilan pengengembangan media Pop Up Book $89,6 \%$ dengan kategori "Baik".
\end{abstract}

Kata kunci: Media Pop Up Book, membaca puisi.

\begin{abstract}
Development of Pop Up Book Media for Learning Poetry Reading on Class I Students of SDN Prambangan. This study aims to develop the Pop Up Book media for learning to read poetry to students of class I SDN Prambangan. The type of this research is development research using instructional development model according to Sadiman, et al. (1996). This study consists of seven stages which include (1) identification of needs, (2) the formulation of objectives, (3) formulation of material points, (4) formulation of measuring tools of success, (5) writing media manuscripts, (6) test/trial, (7) revisions. This research was conducted at SDN Prambangan Jl. Mayjend Sungkono No.1 Prambangan, Kebomas Sub-district, Gresik Regency, East Java. Subjects in this study were students class I SDN Prambangan with the number of students 11 students. Data collection techniques in this study are interviews, validation, and tests using research instruments in the form of interview sheets, expert validation sheets, and test sheets. Data analysis technique used is qualitative. The results of this study indicate that the media Pop Up Book developed by researchers in terms of components of media presentation categorized "Very Good" with validation results reached $94.5 \%$, while in terms of competence categorized "Good" with the results of validation reached 86.7\%. The success rate of Pop Up Book media development shows good results through trials with a limited performance test that reached $93.3 \%$ and categorized as "Excellent" and tested with a wide performance test that reached $86.0 \%$ and categorized " Good ", so the average achievement success of media development Pop Up Book 89,6\% with category " Good ".
\end{abstract}

Keywords: Pop Up Book Media, reading poetry. 


\section{A. PENDahuluan}

Pembelajaran Bahasa dan Sastra Indonesia mengharuskan peserta didik memiliki keterampilan mendengarkan, berbicara, membaca, dan menulis. Untuk memeroleh keterampilan berbahasa, peserta didik biasanya diberi pengajaran secara bertahap. Aspek penting dalam berbahasa yaitu membaca, karena dengan membaca peserta didik mudah mempelajari sesuatu dari bacaan untuk memperoleh pengetahuan. Menurut Herlina, Iswara, \& Kurniadi (2016: 882) peserta didik dapat menguasai keterampilan membaca melalui kegiatan-kegiatan yang mendukung seperti membaca puisi, membaca dalam hati, membaca nyaring, dan sebagainya. Salah satu pembelajaran bahasa dan sastra Indonesia di Sekolah Dasar yang diajarkan kepada peserta didik kelas I yaitu puisi.

Puisi adalah karya sastra yang disampaikan dalam kata-kata untuk menghasilkan ilusi dan imajinasi penulisnya (Hudson dalam Aminuddin, 2011: 134). Puisi juga dapat dipahami sebagai suatu karya sastra yang menggambarkan benda, kejadian maupun perasaan penulis. Tema puisi yang disampaikan pada peserta didik Sekolah Dasar hususnya kelas rendah biasanya tentang hal-hal yang sederhana misalnya tumbuhan, binatang, pahlawan, cita-cita dan sebagainya.

Pembelajaran membaca puisi tidak terlepas dari bangun struktur puisi yang meliputi meliputi (1) bunyi, (2) kata, (3) larik atau baris, (4) dan bait (Aminuddin, 2011: 136). Kegiatan membaca puisi yang diutamakan adalah keterampilan dalam pelafalan, intonasi serta ekspresi ketika membaca puisi. Dalam kegiatan mengajar di Sekolah Dasar, membaca puisi merupakan pembelajaran yang dirasa sulit bagi peserta didik kelas I. Berdasarkan hasil observasi di SDN Prambangan, peserta didik kurang terampil dalam membaca puisi misalnya dalam hal pelafalan dan intonasi serta ekspresi peserta didik saat membaca puisi juga kurang percaya diri, hal ini dikarenakan peserta didik kurang termotivasi untuk belajar membaca puisi saat proses pembelajaran dan yang membuat peserta didik kurang termotivasi belajar salah satunya yaitu bahan ajar yang digunakan.

Pembelajaran membaca puisi khususnya di kelas I SD memang membutuhkan bahan ajar yang mampu menarik minat belajar peserta didik, salah satunya yaitu media pembelajaran. Association of Education and Communication Technology dalam Arsyad (2014: 3) memberi pengertian bahwa media adalah segala sesuatu yang digunakan untuk menyampaikan pesan atau informasi. Dalam proses pembelajaran, media cenderung diartikan sebagai alat-alat grafis, photografis, atau elektronis untuk menerima, memproses dan menyusun kembali suatu pesan atau informasi visual maupun verbal (Arsyad, 2014: 3). Hal ini dapat diartikan bahwa media adalah alat yang digunakan untuk menyampaikan pesan baik berupa grafis maupun elektronik, dan media pembelajaran diartikan sebagai alat yang dapat memberi informasi kepada peserta didik dalam proses pembelajaran yang mampu merangsang pikiran, memusatkan perhatian, membangkitkan minat dan motivasi belajar peserta didik agar terjadi efektifitas pada proses pembelajaran seperti gambar, buku, alat elektronik dan sebagainya. Hal ini sesuai dengan pendapat Sudjana \& Rivai dalam Arsyad (2014: 28) yang mengungkapkan bahwa salah satu manfaat media pembelajaran yaitu pembelajaran akan lebih menarik perhatian siswa sehingga dapat menumbuhkan motivasi belajar.

Media yang digunakan untuk pembelajaran membaca puisi di kelas I SD umumnya menggunakan media gambar dua dimensi. Guru kelas I SDN Prambangan mengatakan bahwa peserta didik di kelas I SDN Prambangan pada saat pembelajaran biasanya menggunakan bahan ajar berupa buku paket, terkadang peserta didik diberi media berupa gambar print out untuk memberi variasi pada pembelajaran. Hal ini juga menjadi salah satu faktor kurangnya motivasi peserta didik untuk belajar membaca puisi. Di era globalisasi ini banyak media kreatif dan inovatif yang mampu membangkitkan minat dan motivasi belajar peserta didik misalnya media elektronik dan media tiga dimensi.

Untuk menciptakan pembelajaran yang menarik dan memotivasi peserta didik, guru harus mempunyai cara baru dalam mengajar salah satunya menggunakan media pembelajaran yang inovatif. Sementara itu, tindakan yang dilakukan peneliti untuk membantu mengatasi permasalahan tersebut yaitu mengembangkan media yang selama ini digunakan peserta didik kelas I SDN Prambangan dalam pembelajaran membaca puisi menjadi media yang menarik dan inovatif. Terkait media inovatif, saat ini banyak jenisnya dan salah satu 
media tersebut yaitu media grafis tiga dimensi. Sehingga dalam penelitian ini peneliti mengembangkan media Pop Up Book untuk pembelajaran membaca puisi di kelas I SDN Prambangan. Hal ini dilakukan karena berdasarkan observasi di SDN Prambangan, guru belum pernah menggunakan media tiga dimensi untuk pembelajaran membaca puisi.

Pop Up Book adalah buku berisi gambar yang bisa ditegakkan dan bergerak ketika halamannya dibuka serta menampilkan gambar yang menarik dan indah sehingga membuat kesan menakjubkan. Hal ini sesuai dengan pernyataan Joko Muktiono dalam Rahmawati (2014: 4) yang menjelaskan pengertian Pop Up Book adalah sebuah buku yang memiliki tampilan gambar yang bisa ditegakkan serta membentuk obyek-obyek yang indah dan dapat bergerak atau memberi efek yang menakjubkan. Namun media Pop Up Book dalam penelitian ini diartikan sebagai buku bergambar bernuansa tiga dimensi yang di dalamnya terdapat puisi anak dan gambar ilustrasi dari puisi tersebut dan jika halamannya dibuka akan menimbulkan kesan menakjubkan dari gambar tiga dimensinya.

Jenis-jenis teknik media Pop Up Book menurut Dzuanda dalam Annisarti \& Rahmah (2016: 12) yaitu Transformation, Volvelles, Peepshow, Pull-Tabs, Carousel, serta Box and Cylinder. Dalam hal ini peneliti menggunakan teknik jenis Transformation dan Box and Cylinder. Manfaat dari media Pop Up Book dalam penelitian ini yaitu (1) untuk memudahkan peserta didik belajar membaca puisi; (2) memudahkan guru dalam menyampaikan materi pelajaran; (3) membuat pembelajaran menjadi bervariasi dan memotivasi peserta didik dalam belajar membaca puisi; (4) menjadikan peserta didik cinta terhadap buku dan gemar membaca; serta (5) memberi motivasi kepada guru untuk menggunakan atau membuat media yang kreatif dan inovatif dalam pembelajaran. Media yang dikembangkan tentu harus sesuai dengan standar, baik dari segi komponen penyajian media maupun dari segi kompetensi.

\section{B. METODE}

Jenis penelitian ini adalah penelitian pengembangan dengan menggunakan model pengembangan instruksional menurut Sadiman, dkk (1996) (Sadiman, Rahardjo, Haryono, \& Rahardjito, 1996: 100). Penelitian ini terdiri dari tujuh tahapan yang meliputi: (1) identifikasi kebutuhan, (2) perumusan tujuan, (3) perumusan butir materi, (4) perumusan alat pengukur keberhasilan, (4) penulisan naskah media, (5) tes/uji coba, (6) revisi. Penelitian ini bersifat kualitatif yang bertujuan untuk mendeskripsikan proses pengembangan media. Penelitian ini dilaksanakan di SDN Prambangan Jl. Mayjend Sungkono No.1 Prambangan, Kecamatan Kebomas, Kabupaten Gresik, Jawa Timur dan dilaksanakan pada semester genap tahun ajaran 2018. Subjek dalam penelitian ini ialah peserta didik kelas I SDN Prambangan dengan jumlah peserta didik 11 siswa dalam satu kelas. Yang menjadi fokus penelitian ini ialah proses pengembangan media Pop Up Book untuk pembelajaran membaca puisi di kelas I SDN Prambangan. Teknik pengumpulan data yang digunakan yaitu wawancara, validasi, dan tes/uji coba. Sehinga insturmen yang digunakan dalam penelitian ini yaitu lembar wawancara, lembar validasi ahli, serta lembar tes/uji coba.

\section{HASIL DAN PEMBAHASAN}

Pengembangan media Pop Up Book memiliki prosedur penelitian yang dilakukan oleh peneliti untuk mendukung kelancaran pengembangan media, diantaranya (1) identifikasi kebutuhan, (2) perumusan tujuan, (3) perumusan butir-butir materi, (4) perumusan alat pengukur keberhasilan, (5) penulisan naskah media, (6) tes/uji coba, (7) revisi. Tahap analisis kebutuhan, peneliti menganalisis kebutuhan peserta didik melalui wawancara dengan guru kelas I SDN Prambangan, hasilnya dari wawancara tersebut menunjukkan bahwa peserta didik kurang terampil dalam membaca puisi seperti pelafalan, intonasi dan ekspresinya. Selain itu peserta didik didik membutuhkan suatu bahan ajar atau media yang menarik, disukai, belum pernah digunakan saat pembelajaran membaca puisi serta berbeda dengan media sebelumnya, misalnya media tiga dimensi.

Tahap perumusan tujuan dalam penelitian ini difokuskan pada peserta didik dan tujuan pembelajaran harus mencakup empat unsur yakni audience, behavior, conditional, dan degree. Tujuan dari kompetensi 
dasar yang telah dipilih 7.2 yaitu membaca puisi anak yang terdiri atas 2-4 baris dengan lafal dan intonasi yang tepat, maka dapat dirumuskan tujuan pembelajaran membaca puisi dalam penelitian ini yaitu (1) melalui media pop up book, peserta didik mampu memahami pengertian puisi dengan baik, (2) melalui media pop up book, peserta didik mampu memahami bangun struktur puisi dengan sesuai dengan baik dan benar, (3) melalui media pop up book, peserta didik mampu membaca puisi anak yang terdiri dari 2-4 baris dengan lafal dan intonasi yang tepat dengan rasa percaya diri. Namun tujuan pembelajaran yang ingin dicapai dalam penelitian ini hanya difokuskan pada keterampilan peserta didik dalam membaca puisi (puisi anak) menggunakan media рор up book. Perumusan butir materi disesuaikan dengan Kompetensi Dasar yang ingin dicapai, dan pada tahap ini diperoleh hasil bahwa materi dalam penelitian ini yaitu pengertian puisi, bangun struktur puisi yang meliputi bunyi, kata, larik atau baris, dan bait, serta contoh puisi anak. Alat pengukur keberhasilan yang dihasilkan peneliti pada tahap perumusan alat pengukur keberhasilan yakni lembar penilaian tes unjuk kerja membaca puisi anak yang digunakan pada saat uji coba media pop up book di kelas.

Tahap selanjutnya yaitu penulisan naskah media. Dalam penulisan naskah media, peneliti melakukan beberapa hal, mulai dari perencanaan, pembuatan media, hingga validasi. Model pop up book yang digunakan peneliti yaitu model Box and Cylinder dan Transformation, sedangkan untuk validasi, peneliti memvalidasikan media kepada dua validator ahli yakni validasi media dari segi komponen penyajian media kepada dosen PGSD UMG Nanang Khoirul Umam, M.Pd. dan validasi media dari segi kompetensi kepada guru kelas I SDN Prambangan Tetty Wahyu Nur, S.Pd. Hasil validasi ahli dari segi komponen penyajian media dapat dilihat pada tabel berikut.

Tabel 1.1 Data hasil validasi ahli komponen penyajian media

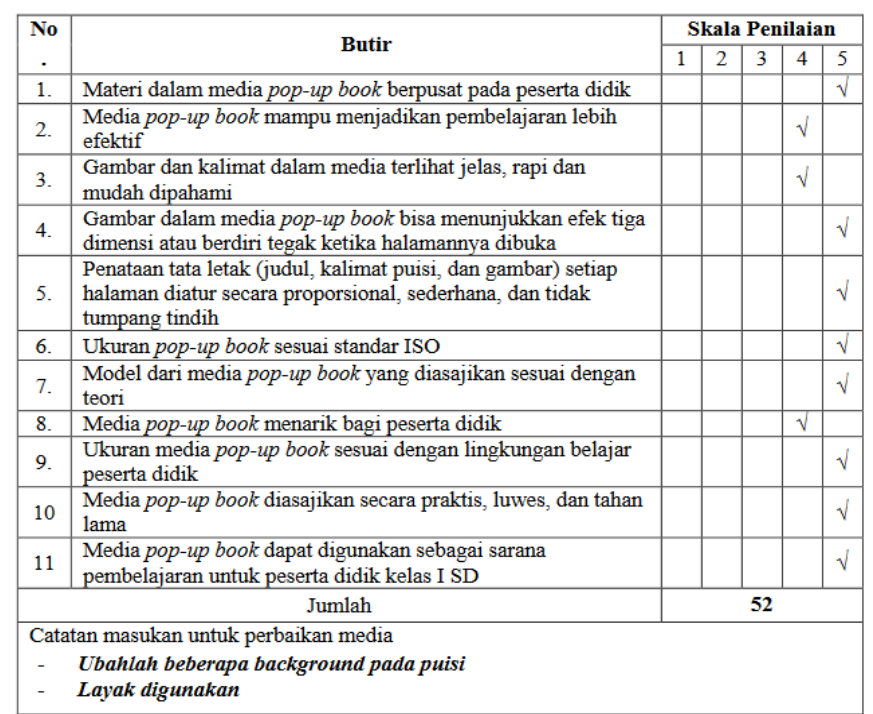

Berdasarkan tabel di atas, hasil validasi kepada validator ahli komponen penyajian media memperoleh jumlah skor 52 dan tingkat persentase dari segi kualitas penyajian media mencapai 94,5\% kategori kualifikasi "Sangat Baik". Hasil catatan dari validator untuk perbaikan media yakni media layak digunakan tetapi perlu adanya pengubahan pada beberapa background pada kalimat puisi agar terlihat cerah.

Tabel 1.2 Data hasil validasi ahli kompetensi 


\begin{tabular}{|c|c|c|c|c|}
\hline \multirow[t]{2}{*}{ No. } & \multirow[t]{2}{*}{ Butir } & \multicolumn{3}{|c|}{$\begin{array}{c}\text { Skala } \\
\text { Penilaian }\end{array}$} \\
\hline & & \begin{tabular}{l|l}
1 & 2 \\
\end{tabular} & \begin{tabular}{|l|l}
3 & \\
\end{tabular} & \\
\hline 1. & $\begin{array}{l}\text { Materi yang ada dalam media pop-up book sesuai dengan } \\
\text { Standar Kompetensi dan Kompetensi Dasar }\end{array}$ & & & \\
\hline 2. & $\begin{array}{l}\text { Media pop-up book mampu menambah motivasi peserta } \\
\text { didik dalam membaca puisi }\end{array}$ & & & $\sqrt{ }$ \\
\hline 3. & $\begin{array}{l}\text { Media pop-up book sesuai dengan karakteristik peserta } \\
\text { didik }\end{array}$ & & & $\sqrt{ }$ \\
\hline 4. & $\begin{array}{l}\text { Puisi yang disampaikan melalui media pop-up book } \\
\text { mudah dibaca dan dipahami oleh peserta didik }\end{array}$ & & & $\sqrt{ }$ \\
\hline 5. & $\begin{array}{l}\text { Tujuan pembelajaran melalui media pop-up book dapat } \\
\text { tersampaikan }\end{array}$ & & & \\
\hline 6. & $\begin{array}{l}\text { Pengembangan media pop-up book relevan dengan topik } \\
\text { yang diajarkan }\end{array}$ & & & $\sqrt{ }$ \\
\hline & Jumlah & \multicolumn{3}{|c|}{26} \\
\hline \multicolumn{5}{|c|}{$\begin{array}{l}\text { Catatan masukan untuk perbaikan media } \\
\text { - Materinya sudah sesuai, cocok untuk siswa } \\
\text { - Tema hewan yang dipilih sesuai dengan judul puisi yang saya ajarkan } \\
\text { pada siswa sebelumnya, selain itu medianya juga bagus dan menarik }\end{array}$} \\
\hline
\end{tabular}

Berdasarkan tabel di atas, hasil validasi kepada validator ahli komponen penyajian media memperoleh jumlah skor memperoleh skor 26 dan kualitas media dari segi kompetensi mencapai 86,7\% dengan kategori "Baik". Tidak ada saran perbaikan dari validator ahli kompetensi.

Selanjutnya tahap tes/uji coba, peneliti melakukan uji coba media pop up book dalam proses pembelajaran dengan dua kali pertemuan. Tes/uji coba dilakukan untuk memperoleh data keberhasilan pengembangan media pop up book terhadap pembelajaran membaca puisi di kelas 1 SDN Prambangan. Uji coba dilakukan oleh peneliti dalam dua kali pertemuan, yakni pertemuan pertama untuk uji coba terbatas dan pertemuan kedua untuk uji coba luas.

\section{a. Proses Pembelajaran Saat Uji Coba Terbatas}

Kegiatan pembelajaran yang dilakukan peneliti pada tahap pertama yakni penyampaian tujuan di mana peneliti menyampaikan tujuan pembelajaran yang akan dilaksanakan. Tahap kedua, peneliti melakukan inti dari pembelajaran di mana peneliti menjelaskan materi tentang puisi kepada peserta didik dengan membawa media pop up book. Peneliti juga mencotohkan cara membaca puisi melalui media pop up book serta menjelaskan pesan yang disampaikan oleh puisi yang ada di dalam media pop up book. Setelah guru memberikan penjelasan dan contoh cara membaca puisi, kemudian peneliti memberi kesempatan kepada beberapa peserta didik untuk mengamati media pop up book, kemudian peneliti meminta maju ke dapan kelas untuk membaca puisi menggunakan media pop up book tersebut, hal ini mendapat respon positif dari peserta didik bahwa seluruh peserta didik ingin mengamati media pop up book dan mencoba ke depan untuk membaca puisi menggunakan media pop up book tersebut, namun peneliti hanya membatasi tiga peserta didik saja untuk mencoba membaca puisi secara bergantian karena nantinya siswa tersebut akan dievaluasi melalui tes unjuk kerja dalam uji coba terbatas. Tahap ketiga yakni penutup, dimana peneliti melakukan pengecekan pemahaman dan memberikan pelatihan lanjutan. Untuk mengecek pemahaman peserta didik terkait materi yang telah dipelajari, peneliti memberikan beberapa pertanyaan lisan. Setelah itu, peneliti memberikan tes kepada beberapa peserta didik berupa tes unjuk kerja membaca puisi guna mengetahui sejauh mana keberhasilan proses pengembangan media pop up book dalam pembelajaran membaca puisi di kelas 1 SD jika media pop up book tersebut digunakan untuk beberapa peserta didik saja. Tes dilakukan oleh peneliti kepada tiga peserta didik yang telah diberi kesempatan untuk mencoba sebelumnya dengan membaca satu puisi yang berbeda di depan kelas secara bergantian. Berikut hasil uji coba terbatas dengan tes unjuk kerja yang dilakukan oleh tiga peserta didik yang dinilai oleh peneliti. Berikut hasil uji coba terbatas dengan tes unjuk kerja yang dilakukan oleh tiga peserta didik yang dinilai oleh peneliti.

Tabel 1.3 Data hasil uji coba terbatas

\begin{tabular}{|l|l|l|l|c|c|}
\hline $\begin{array}{l}\text { N } \\
\text { o. }\end{array}$ & Nama & Aspek & Indikator & $\begin{array}{c}\text { Skala } \\
\text { Penilaian }\end{array}$ & $\begin{array}{c}\text { Nilai } \\
\text { Siswa }\end{array}$ \\
\hline
\end{tabular}




\begin{tabular}{|c|c|c|c|c|c|c|c|c|c|}
\hline & & & & 1 & 2 & 3 & 4 & 5 & \\
\hline \multirow{3}{*}{1} & \multirow{3}{*}{ SV } & $\begin{array}{c}\text { Pelafal } \\
\text { an }\end{array}$ & $\begin{array}{l}\text { Melafalkan bunyi vocal serta } \\
\text { kata-kata dengan tepat dan } \\
\text { jelas }\end{array}$ & & & & & $\sqrt{ }$ & \multirow{3}{*}{86,7} \\
\hline & & $\begin{array}{c}\text { Intona } \\
\text { si }\end{array}$ & $\begin{array}{l}\text { Menyuarakan kalimat puisi } \\
\text { dengan memperhatikan tinggi } \\
\text { rendah nada }\end{array}$ & & & $\sqrt{ }$ & & & \\
\hline & & $\begin{array}{c}\text { Ekspr } \\
\text { esi }\end{array}$ & $\begin{array}{l}\text { Membaca kalimat puisi } \\
\text { dengan mimik wajah yang } \\
\text { menunjukkan rasa percaya diri }\end{array}$ & & & & & $\sqrt{ }$ & \\
\hline \multirow{3}{*}{2} & \multirow{3}{*}{ ANA } & $\begin{array}{c}\text { Pelafal } \\
\text { an }\end{array}$ & $\begin{array}{l}\text { Melafalkan bunyi vocal serta } \\
\text { kata-kata dengan tepat dan } \\
\text { jelas }\end{array}$ & & & & & $\sqrt{ }$ & \multirow{3}{*}{93,3} \\
\hline & & $\begin{array}{c}\text { Intona } \\
\text { si }\end{array}$ & $\begin{array}{l}\text { Menyuarakan kalimat puisi } \\
\text { dengan memperhatikan tinggi } \\
\text { rendah nada }\end{array}$ & & & & $\sqrt{ }$ & & \\
\hline & & $\begin{array}{c}\text { Ekspr } \\
\text { esi }\end{array}$ & $\begin{array}{l}\text { Membaca kalimat puisi } \\
\text { dengan mimik wajah yang } \\
\text { menunjukkan rasa percaya diri }\end{array}$ & & & & & $\sqrt{ }$ & \\
\hline \multirow{3}{*}{3} & \multirow{3}{*}{$\mathrm{TZH}$} & $\begin{array}{c}\text { Pelafal } \\
\text { an }\end{array}$ & $\begin{array}{l}\text { Melafalkan bunyi vocal serta } \\
\text { kata-kata dengan tepat dan } \\
\text { jelas }\end{array}$ & & & & & $\sqrt{ }$ & \multirow{3}{*}{100} \\
\hline & & $\begin{array}{c}\text { Intona } \\
\text { si }\end{array}$ & $\begin{array}{l}\text { Menyuarakan kalimat puisi } \\
\text { dengan memperhatikan tinggi } \\
\text { rendah nada }\end{array}$ & & & & & $\sqrt{ }$ & \\
\hline & & $\begin{array}{c}\text { Ekspr } \\
\text { esi }\end{array}$ & $\begin{array}{l}\text { Membaca kalimat puisi } \\
\text { dengan mimik wajah yang } \\
\text { menunjukkan rasa percaya diri }\end{array}$ & & & & & $\sqrt{ }$ & \\
\hline \multicolumn{9}{|c|}{ Jumlah } & 280 \\
\hline \multicolumn{9}{|c|}{ Rata-rata } & 93,3 \\
\hline
\end{tabular}

Berdasarkan tabel tersebut, hasil uji coba terbatas yang dilakukan pada tiga peserta didik secara acak memperoleh jumlah skor $\mathbf{2 8 0}$ dengan nilai rata-rata keseluruhan 93,3. Sehingga hasil uji coba terbatas media pop up book mencapai tingkat keberhasilan 93,3\% dan berkategori "Sangat Baik".

b. Proses Pembelajaran Saat Uji Coba Luas

Kegiatan pembelajaran yang dilakukan peneliti pada tahap pertama yakni penyampaian tujuan di mana peneliti menyampaikan tujuan pembelajaran yang akan dilaksanakan. Tahap kedua, peneliti melakukan inti dari pembelajaran di mana peneliti menjelaskan kembali materi tentang puisi kepada peserta didik namun hanya sekilas karena pada pertemuan pertama sudah disampaikan. Peneliti kembali mencotohkan cara membaca puisi melalui media pop up book serta menjelaskan pesan yang disampaikan oleh puisi yang ada di dalam media pop up book untuk mengingat kembali cara membaca puisi yang telah disampaikan pada hari sebelumnya. Setelah guru memberikan penjelasan dan contoh cara membaca puisi, kemudian peneliti memberi kesempatan kepada peserta didik maju ke dapan kelas untuk membaca puisi menggunakan media pop up book tersebut guna mengetahui apakah peserta didik masih tertarik untuk belajar membaca puisi atau tidak, dan hasilnya hampir seluruh peserta didik (95\%) masih tertarik untuk belajar membaca puisi menggunakan media pop up book dan ingin mencoba ke depan untuk membaca puisi menggunakan media pop up book tersebut, dalam hal ini peneliti memberi kesempatan kepada seluruh peserta didik yang ingin mencoba ke depan kelas namun mereka hanya diberi kesempatan untuk membaca puisi dua baris karena mengingat waktu yang tidak cukup jika membaca seluruh kalimat puisi. Tahap ketiga yakni penutup, peneliti memberikan pelatihan lanjutan berupa tes unjuk kerja karena mereka sudah memahami materi tentang puisi pada hari sebelumnya. Tes unjuk kerja membaca puisi dilakukan kepada seluruh peserta didik guna mengetahui sejauh mana keberhasilan proses pengembangan media pop up book dalam pembelajaran membaca puisi di kelas 1 SD jika media pop up book tersebut digunakan untuk seluruh peserta didik dan apakah peserta didik yan telah mengikuti tes unjuk kerja pada hari sebelumnya mengalami peningkatan dalam keterampilan membaca 
puisi menggunakan media pop up book. Tes dilakukan oleh peneliti kepada seluruh peserta didik (11 siswa) yang mana siswa tersebut membaca puisi di depan kelas menggunakan media pop up book secara bergantian dengan satu judul puisi yang berbeda. Tes tersebut dinilai oleh peneliti dengan memberikan peneliaian sesuai dengan indikator yang telah ditetapkan. Berikut hasil uji coba secara luas dengan tes unjuk kerja yang dilakukan oleh seluruh peserta didik dalam satu kelas yang dinilai oleh peneliti.

Tabel 1.4 Data hasil uji coba secara luas

\begin{tabular}{|c|c|c|c|c|c|c|c|c|c|}
\hline \multirow{2}{*}{$\begin{array}{l}\mathbf{N} \\
\mathbf{0 .}\end{array}$} & \multirow[t]{2}{*}{ Nama } & \multirow[t]{2}{*}{ Aspek } & \multirow[t]{2}{*}{ Indikator } & \multicolumn{5}{|c|}{$\begin{array}{c}\text { Skala } \\
\text { Penilaian }\end{array}$} & \multirow{2}{*}{$\begin{array}{l}\text { Nilai } \\
\text { Siswa }\end{array}$} \\
\hline & & & & 1 & 2 & 3 & 4 & 5 & \\
\hline \multirow{3}{*}{1} & \multirow{3}{*}{ ANA } & Pelafalan & $\begin{array}{l}\text { Melafalkan bunyi vocal serta kata- } \\
\text { kata dengan tepat dan jelas }\end{array}$ & & & & & $\sqrt{ }$ & \multirow{3}{*}{100} \\
\hline & & Intonasi & $\begin{array}{l}\text { Menyuarakan kalimat puisi dengan } \\
\text { memperhatikan tinggi rendah nada }\end{array}$ & & & & & $\sqrt{ }$ & \\
\hline & & Ekspresi & $\begin{array}{l}\text { Membaca kalimat puisi dengan } \\
\text { mimik wajah yang menunjukkan } \\
\text { rasa percaya diri }\end{array}$ & & & & & $\sqrt{ }$ & \\
\hline \multirow{3}{*}{2} & \multirow{3}{*}{ CAR } & Pelafalan & $\begin{array}{l}\text { Melafalkan bunyi vocal serta kata- } \\
\text { kata dengan tepat dan jelas }\end{array}$ & & & & & $\sqrt{ }$ & \multirow{3}{*}{80} \\
\hline & & Intonasi & $\begin{array}{l}\text { Menyuarakan kalimat puisi dengan } \\
\text { memperhatikan tinggi rendah nada }\end{array}$ & & & $\sqrt{ }$ & & & \\
\hline & & Ekspresi & $\begin{array}{l}\text { Membaca kalimat puisi dengan } \\
\text { mimik wajah yang menunjukkan } \\
\text { rasa percaya diri }\end{array}$ & & & & $\sqrt{ }$ & & \\
\hline \multirow[b]{3}{*}{3} & \multirow[b]{3}{*}{ EAS } & Pelafalan & $\begin{array}{l}\text { Melafalkan bunyi vocal serta kata- } \\
\text { kata dengan tepat dan jelas }\end{array}$ & & & & $\sqrt{ }$ & & \multirow[b]{3}{*}{80} \\
\hline & & Intonasi & $\begin{array}{l}\text { Menyuarakan kalimat puisi dengan } \\
\text { memperhatikan tinggi rendah nada }\end{array}$ & & & $\sqrt{ }$ & & & \\
\hline & & Ekspresi & $\begin{array}{l}\text { Membaca kalimat puisi dengan } \\
\text { mimik wajah yang menunjukkan } \\
\text { rasa percaya diri }\end{array}$ & & & & & $\sqrt{ }$ & \\
\hline \multirow{3}{*}{4} & \multirow{3}{*}{ FZEK } & Pelafalan & $\begin{array}{l}\text { Melafalkan bunyi vocal serta kata- } \\
\text { kata dengan tepat dan jelas }\end{array}$ & & & & & $\sqrt{ }$ & \multirow{3}{*}{86,7} \\
\hline & & Intonasi & $\begin{array}{l}\text { Menyuarakan kalimat puisi dengan } \\
\text { memperhatikan tinggi rendah nada }\end{array}$ & & & & $\sqrt{ }$ & & \\
\hline & & Ekspresi & $\begin{array}{l}\text { Membaca kalimat puisi dengan } \\
\text { mimik wajah yang menunjukkan } \\
\text { rasa percaya diri }\end{array}$ & & & & $\sqrt{ }$ & & \\
\hline \multirow{3}{*}{5} & \multirow{3}{*}{ MGS } & Pelafalan & $\begin{array}{l}\text { Melafalkan bunyi vocal serta kata- } \\
\text { kata dengan tepat dan jelas }\end{array}$ & & & & $\sqrt{1}$ & & \multirow{3}{*}{80} \\
\hline & & Intonasi & $\begin{array}{l}\text { Menyuarakan kalimat puisi dengan } \\
\text { memperhatikan tinggi rendah nada }\end{array}$ & & & & $\sqrt{ }$ & & \\
\hline & & Ekspresi & $\begin{array}{l}\text { Membaca kalimat puisi dengan } \\
\text { mimik wajah yang menunjukkan } \\
\text { rasa percaya diri }\end{array}$ & & & & $\sqrt{ }$ & & \\
\hline \multirow{3}{*}{6} & \multirow{3}{*}{ MNF } & Pelafalan & $\begin{array}{l}\text { Melafalkan bunyi vocal serta kata- } \\
\text { kata dengan tepat dan jelas }\end{array}$ & & & & & $\sqrt{ }$ & \multirow{3}{*}{86,7} \\
\hline & & Intonasi & $\begin{array}{l}\text { Menyuarakan kalimat puisi dengan } \\
\text { memperhatikan tinggi rendah nada }\end{array}$ & & & $\sqrt{ }$ & & & \\
\hline & & Ekspresi & $\begin{array}{l}\text { Membaca kalimat puisi dengan } \\
\text { mimik wajah yang menunjukkan } \\
\text { rasa percaya diri }\end{array}$ & & & & & $\sqrt{ }$ & \\
\hline \multirow{3}{*}{7} & \multirow{3}{*}{ MTR } & Pelafalan & $\begin{array}{l}\text { Melafalkan bunyi vocal serta kata- } \\
\text { kata dengan tepat dan jelas }\end{array}$ & & & & & $\sqrt{ }$ & \multirow{3}{*}{93,3} \\
\hline & & Intonasi & $\begin{array}{l}\text { Menyuarakan kalimat puisi dengan } \\
\text { memperhatikan tinggi rendah nada }\end{array}$ & & & & $\sqrt{ }$ & & \\
\hline & & Ekspresi & $\begin{array}{l}\text { Membaca kalimat puisi dengan } \\
\text { mimik wajah yang menunjukkan }\end{array}$ & & & & & $\sqrt{ }$ & \\
\hline
\end{tabular}




\begin{tabular}{|c|c|c|c|c|c|c|c|}
\hline & & & rasa percaya diri & & & & \\
\hline \multirow{3}{*}{8} & \multirow{3}{*}{ RRR } & Pelafalan & $\begin{array}{l}\text { Melafalkan bunyi vocal serta kata- } \\
\text { kata dengan tepat dan jelas }\end{array}$ & & & $\sqrt{ }$ & \multirow{3}{*}{73,3} \\
\hline & & Intonasi & $\begin{array}{l}\text { Menyuarakan kalimat puisi dengan } \\
\text { memperhatikan tinggi rendah nada }\end{array}$ & $\sqrt{ }$ & & & \\
\hline & & Ekspresi & $\begin{array}{l}\text { Membaca kalimat puisi dengan } \\
\text { mimik wajah yang menunjukkan } \\
\text { rasa percaya diri }\end{array}$ & $\sqrt{ }$ & & & \\
\hline \multirow{3}{*}{9} & \multirow{3}{*}{ SV } & Pelafalan & $\begin{array}{l}\text { Melafalkan bunyi vocal serta kata- } \\
\text { kata dengan tepat dan jelas }\end{array}$ & & & $\sqrt{ }$ & \multirow{3}{*}{93,3} \\
\hline & & Intonasi & $\begin{array}{l}\text { Menyuarakan kalimat puisi dengan } \\
\text { memperhatikan tinggi rendah nada }\end{array}$ & & $\sqrt{ }$ & & \\
\hline & & Ekspresi & $\begin{array}{l}\text { Membaca kalimat puisi dengan } \\
\text { mimik wajah yang menunjukkan } \\
\text { rasa percaya diri }\end{array}$ & & & $\sqrt{ }$ & \\
\hline \multirow{3}{*}{10} & \multirow{3}{*}{$\mathrm{TZH}$} & Pelafalan & $\begin{array}{l}\text { Melafalkan bunyi vocal serta kata- } \\
\text { kata dengan tepat dan jelas }\end{array}$ & & & $\sqrt{ }$ & \multirow{3}{*}{100} \\
\hline & & Intonasi & $\begin{array}{l}\text { Menyuarakan kalimat puisi dengan } \\
\text { memperhatikan tinggi rendah nada }\end{array}$ & & & $\sqrt{ }$ & \\
\hline & & Ekspresi & $\begin{array}{l}\text { Membaca kalimat puisi dengan } \\
\text { mimik wajah yang menunjukkan } \\
\text { rasa percaya diri }\end{array}$ & & & $\sqrt{ }$ & \\
\hline \multirow{3}{*}{11} & \multirow{3}{*}{ VPY } & Pelafalan & $\begin{array}{l}\text { Melafalkan bunyi vocal serta kata- } \\
\text { kata dengan tepat dan jelas }\end{array}$ & & $\sqrt{ }$ & & \multirow{3}{*}{73,3} \\
\hline & & Intonasi & $\begin{array}{l}\text { Menyuarakan kalimat puisi dengan } \\
\text { memperhatikan tinggi rendah nada }\end{array}$ & $\sqrt{ }$ & & & \\
\hline & & Ekspresi & $\begin{array}{l}\text { Membaca kalimat puisi dengan } \\
\text { mimik wajah yang menunjukkan } \\
\text { rasa percaya diri }\end{array}$ & & $\sqrt{ }$ & & \\
\hline \multicolumn{7}{|c|}{ Jumlah } & 946,6 \\
\hline \multicolumn{7}{|c|}{ Rata-rata } & 86,0 \\
\hline
\end{tabular}

Berdasarkan tabel tersebut, hasil dari tes unjuk kerja secara luas yang dilakukan pada seluruh peserta didik dalam satu kelas (11 siswa) memperoleh jumlah nilai 946,6 dengan nilai rata-rata 86,0 sehingga tingkat ketercapaian uji coba secara luas dengan tes unjuk kerja membaca puisi menggunakan media pop up book mencapai $\mathbf{8 6 \%}$ dan berkategori "Baik".

Dari kedua nilai rata-rata ketercapaian hasil uji coba tersebut jika diambil kesimpulan maka media pop up book yang dikembangkan peneliti merupakan media yang "Baik" dengan tingkat ketercapaian 89,6\% (93,3\% ditambah 86,0\% dibagi 2) sehingga baik digunakan untuk pembelajaran membaca puisi di kelas 1 Seklah Dasar. Berikut data hasil rekapitulasi dari kedua hasil tes/uji coba.

Tabel 1.5 Rekapitulasi ketercapaian hasil uji coba melalui tes unjuk kerja dengan media pop up book secara umum

\begin{tabular}{|c|c|c|c|}
\hline Hasil/kriteria & $\begin{array}{c}\text { Uji coba } \\
\text { terbatas }\end{array}$ & $\begin{array}{c}\text { Uji coba } \\
\text { luas }\end{array}$ & Kesimpulan \\
\hline $\begin{array}{c}\text { Ketercapaian hasil tes/uji } \\
\text { coba }\end{array}$ & $93,3 \%$ & $86 \%$ & $89,6 \%$ \\
\hline Kategori & Sangat Baik & Baik & Baik \\
\hline
\end{tabular}

Tahap penelitian yang terakhir yaitu tahap revisi. Pada tahap ini, revisi dilakukan jika pada saat uji coba ditemukan hal-hal yang perlu direvisi. Dan berdasarkan hasil penelitian yang telah dijabarkan di atas, maka media pop up book yang dikembangkan peneliti tidak perlu direvisi, hanya saja beberapa background pada kalimat puisi perlu diganti agar terlihat cerah. 


\section{SIMPULAN}

Berdasarkan penelitian yang telah dilakukan, media pop up book yang dikembangkan peneliti dalam segi komponen penyajian media berkategori "Sangat Baik" dengan hasil validasi mencapai 94,5\%, sedangkan dari segi kompetensi berkategori "Baik" dengan hasil validasi mencapai $86,7 \%$. Uji coba media dilaksanakan melalui proses pembelajaran membaca puisi di kelas I SDN Prambangan menggunakan media pop up book dan dengan memberikan tes unjuk kerja membaca puisi anak menggunakan media pop up book. Tingkat keberhasilan pengembangan media pop up book menunjukkan hasil yang baik melalui hasil uji coba dengan tes unjuk kerja membaca puisi anak menggunakan media pop up book secara terbatas (3 siswa) mencapai 93,3\% dan berkategori "Sangat Baik" serta hasil uji coba dengan tes unjuk kerja membaca puisi menggunakan media pop up book secara luas (11 siswa) mencapai 86,0\% dan berkategori "Baik", sehingga rata-rata kedua hasil uji coba melalui tes unjuk kerja membaca puisi menggunakan media pop up book mencapai $89,6 \%$ berkategori "Baik".

\section{E. DAFTAR PUSTAKA}

Aminuddin. (2011). Pengantar Apresiasi Karya Sastra. Bandung: Sinar Baru Algensindo.

Annisarti, S., \& Rahmah, E. (2016). Model Pop Up Book Keluarga untuk Mempercepat Kemampuan Membaca Anak Kelas Rendah Sekolah Dasar. Jurnal Ilmu Informasi Perpustakaan dan Kearsipan, 10-21. Diakses 7 Maret 2018 dari Universitas Negeri Padang,. https://www.google.co.id/url?q=http://ejournal.unp.ac.id/index.php/iipk/article/viewFile/628 $\underline{81}$

Arifin, Z. (2013). Evaluasi Pembelajaran. Bandung: PT. Remaja Rosdakarya.

Arsyad, A. (2014). Media Pembelajaran. Jakarta: PT. Raja Grafindo Persada.

Herlina, R., Iswara, P. D., \& Kurniadi, Y. (2016). Penerapan Metode ATM (Amati, Tiru, dan Modifikasi) Berbantuan Media Audiovisul Untuk Meningkatkan Keterampilan Membaca Puisi. Jurnal Pena Ilmiah, 881-890. Diakses 18 Februari 2018 dari UPI Sumedang,. http://ejournal.upi.edu/index.php/penailmiah/article/viewFile/2878/1912

Pravitasari, A. (2012). Pengembangan Media Puzzle Gambar Seri Untuk Pembelajaran Menulis Cerpen Pada Siswa Kelas X-1 SMA Negeri Plandaan Jombang. 0-216.

Rahmawati, N. (2014). Pengaruh Media Pop-Up Book Terhadap Penguassaan Kosakata Anak Usia 5-6 Tahun TK Putera Harapan. Jurnal Mahasiswa, 1-6. Diakses 18 Februari 2018 dari Universitas Negeri Surabaya,.

https://www.google.co.id/url?q=http://jurnalmahasiswa.unesa.ac.id/index.php/paudteratai/article/view/6917

Riduwan. (2003). Dasar-dasar Statistika. Bandung: Alfabeta.

Sadiman, A. S., Rahardjo, R., Haryono, A., \& Rahardjito. (1996). Media Pendidikan. Jakarta: PT. Raja Grafindo Persada.

Sugiyono. (2015). Metode penelitian Pendidikan. Bandung: ALFABETA.

Tarigan, H. G. (2008). Membaca Sebagai Suatu Keterampilan Membaca. Bandung: Angkasa Bandung.

Waluyo, H. J. (1987). Teori dan Apresiasi Puisi. Jakarta: Erlangga.

http://wp.robertsabuda.com/wp-content/uploads (Diakses pada tanggal 21 Mei 2018). https://pixabay.com (Diakses pada tanggal 21 Mei 2018). 